\title{
Shiga Toxin (Stx) Gene Detection and Verotoxigenic Potentials of Non- 0157 Escherichia Coli Isolated from Fermented Fresh Cow Milk (Nono) Sold in Selected Cities in Nigeria
}

\author{
*1S. A. Enabulele and 20.0. Nwankiti \\ ${ }^{1}$ Department of Basic Sciences, Benson Idahosa University, Benin City, Nigeria \\ ${ }^{2}$ National Veterinary Research Institute, Vom, Plateau State, Nigeria \\ [Corresponding author: e-mail: senabulele@biu.edu.ng, amadinbulele@yahoo.com; D : +2348033526243]
}

\begin{abstract}
Non-0157 Escherichia coli, isolated from Nono (fermented fresh cow milk) sampled from four major Nigerian cities, namely, Abuja, Benin City, Lagos and Onitsha were investigated for the presence shiga toxins (stx1 and stx2) genes using PCR technique and for their verotoxigenic potentials using tissue culture assay on Vero cells. The result of the investigation reveal that out of the total 800 samples collected, $268(33 \%)$ had $E$. coli and out of this, 217 (81\%) had non-0157 E. coli. Total number of non$0157 \mathrm{E}$. coli isolated from the 217 samples was 503. Shiga toxin gene detection of the isolates revealed that $199(40 \%)$ had stx1 gene alone, $192(38 \%)$ had stx2 gene alone, 4(1\%) had both stx 1 and stx 2 genes while $108(21 \%)$ had none of the two genes. Tissue culture assay on Vero cells indicate that there is a strong relationship between the presence of stx genes and their degree of cytotoxic effect on vero cells as over $80 \%$ of the isolates without the genes exhibited weak cytotoxic effect whereas over $80 \%$ of those with the stx genes exhibited varying degrees of cytotoxic effects ranging from strong to excellently strong. This study provides evidence of presence of non-0157 E. coli in our food system and can be of serious health challenge to consumers.
\end{abstract}

Keywords: Non- 0157 Escherichia coli, Shiga toxins, Verotoxigenic, Nono, Fermented Milk

\section{INTRODUCTION}

Escherichia coli are normal inhabitants of the gastrointestinal tract of animals and humans. Beneficial strains of $E$. coli typically colonize the infant's gastrointestinal tract within a few hours after birth (Blackburn and McCarthy; 2000, Franzolin et al., 2005) andthe presence of the bacterial population in the intestine is reported to suppress the growth of other harmful bacteria and have been implicated in the synthesis of appreciable amounts of B vitamins (Nataro and Kaper, 1998). However, the organism has been implicated severally as a very important food borne pathogen (Hussein, 2007). Many strains of $E$. coli have infarct been identified as pathogens inducing serious gastrointestinal diseases and even causing death in humans (Kaper et al., 2004). Amongst these are those referred to as Shiga or Vero toxin producing $E$. coli.

Bosilevac and Koohmaraie (2011) stated that more than 70 different serotypes of Shiga toxinproducing Escherichia coli (STEC) are known that cause disease in humans. Illnesses caused by STEC ranges from mild diarrhoea to bloody diarrhoea to hemorrhagic colitis $(\mathrm{HC})$ and haemolytic uremic syndrome (HUS). E. coli $0157: \mathrm{H} 7$ is the STEC strain most often associated with the most severe forms of disease and have extensively been studied (Scallan et al., 2011). However, numerous non0157 STEC isolates have also been linked to food- borne illnesses and outbreaks of disease (Johnson et al., 2006).

Basically, most of the known $E$. coli outbreaks have been linked in one way or the other to food sources (Pradel et al., 2001, Solomon et. al., 2002, Hussein 2007). Fermented fresh cow milk (nono) is one of such food produce and it has been implicated severally as possible source of transmitting pathogenic microorganisms (Abdalla and El-Zubeir, 2006; Ekici et al., 2004; Adesiyun et al., 1995). Nono is an opaque white to milky liquid food drink prepared and sold predominantly by wives of the nomadic Hausa/Fulani herdsmen who control over $80 \%$ of Nigeria's cattle production. It is a nutritiously rich food product whose 
consumption is known to transverse the Saharan tribes of West African sub-region extending to the inhabitants of the Mediterranean region and the Middle East (Ogbonna, 2011). Nono is reported to be nutritionally rich, containing appreciable amount of essential amino acids, calcium, phosphorous and vitamins $A, C, E$ and the $B$ complex (Nebedum and Obiakor, 2007).

Although other investigators have analysed the microbiological quality of Nono sold in Nigeria (Ogbonna, 2011; Obi and Ikenebomeh, 2007; Adesiyun et al., 1995), their reports have been of general nature and none have targeted the possibility of isolating this group of potentially dangerous pathogenic shiga- toxin producing $E$. coli from the food product.

Consequent upon the above and the need to augment the scarce information on the organism in Nigeria, this research work was undertaken to isolate non- $0157 \mathrm{E}$. coli from fermented fresh cow milk (nono) sold in selected cities in Nigeria and thereafter do a shiga- toxin (stx) gene detection of all the isolates. Tissue culture assay was also performed to determine the toxigenic potentials of all the isolates on Vero cells.

\section{MATERIALS AND METHODS}

Fermented milk (nono) samples were collected randomly from different locations in four selected cities in Nigeria namely, Abuja, Benin City, Lagos and Onitsha. A total of 200 milk samples were collected from each city giving an overall total of 800 samples analysed. Sampling and screening was done between January, 2014 and December, 2014. Samples were collected in duplicates at point of sales in sterile plastic containers, labelled and transported to the laboratory for immediate analysis.

\section{Isolation and Identification of $E$. coli Isolates}

The milk samples were homogenized in a sterile test tube by mixing with a sterile glass rod, thereafter $1 \mathrm{ml}$ of the homogenate milk samples were suspended in $9 \mathrm{ml}$ buffered peptone water. Serial dilutions of up to $10^{-5}$ were then made and $1 \mathrm{ml}$ of each was plated on Eosin methylene blue (EMB) agar and incubated at $37^{\circ} \mathrm{C}$ for $24 \mathrm{~h}$. Pure cultures exhibiting typical dark colonies, and black centres with green metallic sheen which is characteristic of $E$. coli on EMB were then made in readiness for biochemical tests. Biochemical tests to confirm $E$. coli was done using the API 20E test strips and in accordance with the method described by Holt et al. (1994).

\section{Identification and Characterisation of Non- 0157:H7 E. coli}

Pure cultures of all positive E. coli were cultured on cefixim- tellurite sorbitol-MacConkey (CTSMAC) agar using the method of VernozyRozand (1997) and incubated at $37^{\circ} \mathrm{C}$ for 18 $24 \mathrm{~h}$. All sorbitol fermenters which showed light to dark pinkish colour on CT-SMCA suspected to be colon

ies of non 0157 were selected and used for further analysis.

\section{Shiga toxin (stx) Gene analysis}

Molecular procedures using PCR technique targeting the stx 1 and stx 2 genes was done with primers $(s t \times 1$; forward = CGCTGAATGTCATTCGCTCTGC; reverse = CGTGGTATAGCTACTGTCACC; stx2 ; forward = CTTCGGTATCCTATTCCCGG; reverse = CTGCTGTGACAGTGACAAAACGC)

manufactured by Primerdesign Ltd, UK, according to method outlined by Blanco et al. (2003). DNA extraction was done according to Sambrook and Russell, (2001). The mixture for the amplification of $s t x 1$ and stx2 genes consisted of $2.5 \mu \mathrm{l}$ of PCR buffer $(10 \mathrm{mM}$ Tris$\mathrm{HCl} \mathrm{pH} \mathrm{9,50mM} \mathrm{KCl}$, and $0.1 \%$ Triton X-100), $2.5 \mathrm{mM} \mathrm{MgCl} 2,0.2 \mathrm{mM}$ of each dNTP, $1 \mu \mathrm{M}$ of each primer and $1.25 \mathrm{U}$ of Taq polymerase, in a final volume of $25 \mu$. Amplification was done with a 96 well dual head Pelter Thermocycler (DNA engine Model PTC-200). The amplification conditions consisted of an initial denaturation step at $94^{\circ} \mathrm{C}$ for $4 \mathrm{~min}$, and 30 cycles of $94^{\circ} \mathrm{C}$ for $1 \mathrm{~min}$ (denaturation), $55^{\circ} \mathrm{C}$ for $1 \mathrm{~min}$ (annealing), and $72^{\circ} \mathrm{C}$ for $1 \mathrm{~min}$ (extension), and a final step at $72^{\circ} \mathrm{C}$ for $10 \mathrm{~min}$. PCR products were analyzed by electrophoresis on $1 \%$ agarose gel and visualized by ethidium bromide staining in a UV trans-illuminator. All molecular work was done 
at the Lahor research and diagnostic Laboratory, Benin City.

\section{Tissue Culture Assay for Verotoxin production}

Preparation of extract for tissue culture assay was done by first inoculating pure cultures of all test isolates maintained on nutrient agar slants in $5 \mathrm{ml}$ Trypticase soy broth (TSB) and incubated overnight at $37^{\circ} \mathrm{C}$; $500 \mu$ of the inoculated Trypticase soy broth was then transferred onto $5 \mathrm{ml}$ brain heart infusion broth (BHIB) and incubated at $37^{\circ} \mathrm{C}$ for $24 \mathrm{~h}$. Extract filtrate was obtained by first centrifuging $1 \mathrm{ml}$ of the incubated BHIB at $4000 \times \mathrm{xg}$ using a Gemmyco centrifuge model PLC-025 to reduce debris and aid filtration. The supernatant was then passed through a $0.20 \mu \mathrm{m}$ pore-size Titan Two $30 \mathrm{~mm}$ diameter nylon membrane syringe filter (SMI-LabHut Ltd UK). Sterility check was done on all filtrate by plating an aliquot of the filtrate on MacConkey agar and incubated overnight at $37^{\circ} \mathrm{C}$. Plates showing no growth were considered sterile.

The BHIB filtrates were screened for verocytotoxicity by using a modified method of Rahn et al. (1996). Filtrate was used to cause swelling, rounding or dissemination of vero cells prepared by Passaging on monolayer in 96 well micro titre plates. Vero cells for the cell culture assay was prepared by trysinizing with $1 \mathrm{X}$ trypsin - EDTA and seeded in a 96 well flat bottom micro titre plate at $4 \times 105 /$ well and using $1 \%$ Glasgow Minimum Essential Medium (GMEM) with addition of Hepes buffer as the growth medium. Growth medium was replaced with fresh GMEM after aspiration before cells were infected with filtrate. Undiluted $100 \mu$ l of the filtrate was transferred to the first well of each plate containing the vero cells and 1:2 dilutions in each of the subsequent wells (i.e. $100 \mu \mathrm{l}, 50 \mu \mathrm{l}, 25 \mu \mathrm{l}, 12.5 \mu \mathrm{l}, 6.25 \mu \mathrm{l}$ and $3.125 \mu \mathrm{l}$ ) were then done. The plates were incubated at $37{ }^{\circ} \mathrm{C}$ and examined for verotoxigenic activity after $3 \mathrm{hrs}$, 6hrs, $12 \mathrm{~h} 24 \mathrm{~h}$ and $48 \mathrm{~h}$ using an inverted microscope. Degree of verotoxigenic effect on each of the vero cells were noted and recorded after each examination. Picture of each well was taken before and after infection. Wells containing less than $25 \%$ cytotoxic effect after $48 \mathrm{~h}$ end point were considered weak, greater than $25 \%$ but less than $50 \%$ fairly strong, greater than $50 \%$ but less than $75 \%$ strong, greater than $75 \%$ but less than $90 \%$ very strong and greater than $90 \%$ excellently strong. Tissue culture assay was done at the Morbilic and Related Virus Laboratory, National Veterinary Research Institute (NVRI), Vom, Jos Nigeria.

\section{RESULTS}

The results of this study showed that out of the 800 samples collected, $268(33.50 \%)$ had $E$. coli Isolated from them and out of this number, 217 had non- E. coli 0157(Table 1). In all, 503 non -0157 E. coli were isolated with Onitsha recording the highest number of 164 , while Abuja recorded the least number of isolates (98).

Table 1: Prevalence and Number of non -0157 E. coli Isolated from Fermented Fresh Milk (Nono)

\begin{tabular}{lcccc}
\hline City & $\begin{array}{c}\text { No. of } \\
\text { samples } \\
\text { analysed }\end{array}$ & $\begin{array}{c}\text { No. of samples } \\
\text { with E. coli }(\%)^{*}\end{array}$ & $\begin{array}{c}\text { No. of samples } \\
\text { with Non }-0157 \\
\text { E. coli }(\%)^{*}\end{array}$ & $\begin{array}{c}\text { No. of Non- 0157 } \\
\text { E. coli isolated }\end{array}$ \\
\hline Abuja & 200 & $53(26.50)$ & $42(21.0)$ & 93 \\
Benin City & 200 & $48(24.0)$ & $41(20.5)$ & 107 \\
Lagos & 200 & $81(40.50)$ & $64(32.0)$ & 139 \\
Onitsha & 200 & $86(43.0)$ & $70(35.0)$ & 164 \\
Total & 800 & $268(33.50)$ & $217(27.13)$ & 503 \\
\hline
\end{tabular}

${ }^{*}(\%)$ based on number of samples analysed

The result of the shiga toxin (stx) gene detection is presented in Table 2. The result showed that out of the 503 isolates analysed, 199(40\%) had stx1 gene alone, $192(38 \%)$ had 
stx2 gene alone, 4(1\%) had both stx 1 and stx 2

genes. genes while $108(21 \%)$ had none of the two

Table 2: Shiga Toxin (stx) Gene Detection in non -0157 E. coli Isolates From Nono Sold in Nigeria

\begin{tabular}{llllll}
\hline City & $\begin{array}{l}\text { No. of Isolates } \\
\text { tested }\end{array}$ & $\begin{array}{l}\text { No. with stx 1 } \\
\text { only }\end{array}$ & $\begin{array}{l}\text { No. with stx 2 } \\
\text { only }\end{array}$ & $\begin{array}{l}\text { No. with both } \\
\text { stx 1 and stx 2 }\end{array}$ & $\begin{array}{l}\text { No. with no } \\
\text { stx gene }\end{array}$ \\
\hline Abuja & 93 & $39(42 \%)$ & $36(39 \%)$ & $1(1 \%)$ & $17(18 \%)$ \\
Benin & 107 & $52(48 \%)$ & $35(33 \%)$ & Nil $(0 \%)$ & $20(19 \%)$ \\
Lagos & 139 & $41(30 \%)$ & $62(45 \%)$ & $2(1 \%)$ & $34(24 \%)$ \\
Onitsha & 164 & $67(41 \%)$ & $59(36 \%)$ & $1(1 \%)$ & $37(22 \%)$ \\
Total & 503 & $199(40 \%)$ & $192(38 \%)$ & $4(1 \%)$ & $108(21 \%)$ \\
\hline
\end{tabular}

The result of the tissue culture assay on Vero cells presented in Table 3 revealed that those with no stx genes exhibited weak cytotoxic effect on Vero cells whereas those with the stx genes exhibited varying degrees of cytotoxic effects ranging from strong to excellently strong. Plates 1 to 3 show the picture, of the Vero cells indicating their state before and after infection with the toxin extracts.

Table 3: Vero Toxin Analysis of non - 0157 E. coli Isolates From Nono Sold in Nigeria

\begin{tabular}{|c|c|c|c|c|c|c|c|}
\hline \multirow[b]{2}{*}{ City } & \multirow[b]{2}{*}{ Shiga toxin } & \multirow[b]{2}{*}{$\begin{array}{l}\text { No. } \\
\text { Tested }\end{array}$} & \multicolumn{5}{|c|}{ Degree of Verotoxigenicity } \\
\hline & & & $\begin{array}{l}\leq 25 \% \\
\text { (Weak } \\
\text { cytotoxic } \\
\text { effect) }\end{array}$ & $\begin{array}{l}\text { Btw } 26 \\
\text { and } 50 \% \\
\text { (Strong } \\
\text { cytotoxic } \\
\text { effect) }\end{array}$ & $\begin{array}{l}\text { Btw } 51 \text { and } \\
75 \% \text { (Very } \\
\text { strong } \\
\text { cytotoxic } \\
\text { effect) }\end{array}$ & $\begin{array}{l}\text { Btw } 76 \text { and } \\
90 \% \text { (Very } \\
\text { very strong } \\
\text { cytotoxic } \\
\text { effect) }\end{array}$ & $\begin{array}{l}>90 \% \\
\text { Excellently } \\
\text { strong } \\
\text { cytotoxic } \\
\text { effect }\end{array}$ \\
\hline \multirow[t]{4}{*}{ Abuja } & stx1 & 39 & 5 & 18 & 13 & 3 & Nil \\
\hline & Stx 2 & 36 & 2 & 11 & 21 & 2 & Nil \\
\hline & Stx 1 and 2 & 1 & Nil & Nil & 1 & Nil & 1 \\
\hline & No stx & 17 & 13 & 4 & Nil & Nil & Nil \\
\hline \multirow[t]{4}{*}{ Benin } & stx1 & 52 & 11 & 19 & 17 & 4 & 1 \\
\hline & Stx 2 & 35 & 5 & 17 & 15 & 4 & 2 \\
\hline & Stx 1 and 2 & Nil & Nil & Nil & Nil & Nil & Nil \\
\hline & No stx & 20 & 16 & 3 & 1 & Nil & Nil \\
\hline \multirow[t]{4}{*}{ Lagos } & $s t x 1$ & 41 & 5 & 12 & 15 & 8 & 1 \\
\hline & Stx 2 & 62 & 8 & 25 & 36 & 9 & 4 \\
\hline & Stx 1 and 2 & 2 & Nil & Nil & Nil & 2 & Nil \\
\hline & No stx & 34 & 29 & 4 & 1 & Nil & Nil \\
\hline \multirow[t]{5}{*}{ Onitsha } & $s t \times 1$ & 67 & 7 & 29 & 24 & 5 & 2 \\
\hline & Stx 2 & 59 & 5 & 30 & 32 & 7 & 2 \\
\hline & Stx 1 and 2 & 1 & Nil & Nil & Nil & 1 & Nil \\
\hline & No stx & 37 & 28 & 5 & 3 & 1 & Nil \\
\hline & $s t x 1$ & 199 & $28(14 \%)$ & 78 (39\%) & $69(35 \%)$ & $20(10 \%)$ & $4(2 \%)$ \\
\hline \multirow[t]{3}{*}{ Total } & Stx 2 & 192 & $17(9 \%)$ & $71(37 \%)$ & $82(43 \%)$ & $16(8 \%)$ & $6(3 \%)$ \\
\hline & Stx 1 and 2 & 4 & Nil & Nil & $1(25 \%)$ & $3(75 \%)$ & Nil \\
\hline & No stx & 108 & $86(80 \%)$ & $16(14 \%)$ & $5(4 \%)$ & $1(2 \%)$ & Nil \\
\hline
\end{tabular}




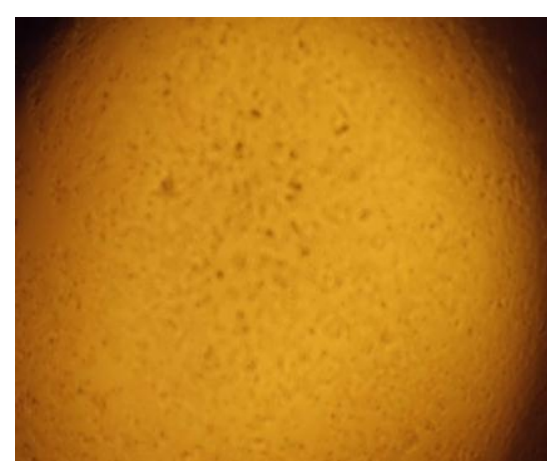

Plate 1: Uninfected Vero Cells still intact at both beginning and end of experiment

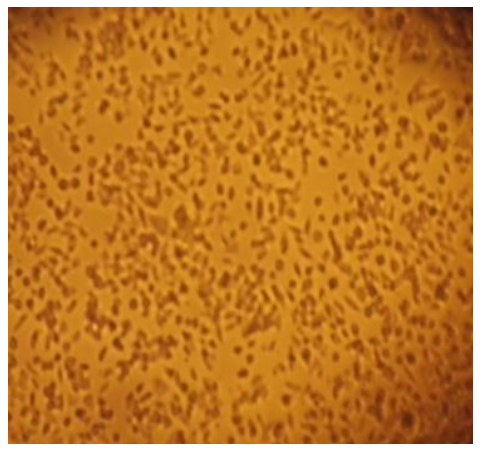

Plate 2: Infected Cells Exhibiting rounding and clumping after infection with toxin

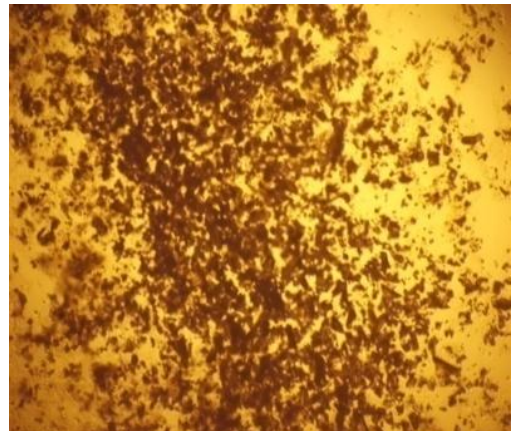

Plate 3: Infected Vero cells showing very high degrees of cytotoxic effect on it with the Vero cells detached and completely being eroded at the end of experiment

\section{DISCUSSION}

Shiga toxin-producing Escherichia coli (STEC) are reported to be the leading cause of bacterial enteric infections worldwide (CDC, 2009), and have been associated with foodborne diseases which range from uncomplicated diarrhoea to haemolytic uremic syndrome (HUS). Fey et al., (2000) reported that several studies from United States, Canada, Europe, Argentina and Australia suggest that non-0157:H7 STEC infections are as prevalent or more so, than 0157:H7 infections. The finding in this study which revealed that $81 \%$ of the $E$. coli isolated from nono was non- 0157:H7 confirmed the report of Johnson et al. (1996) who suggested that humans are more exposed to non- 0157:H7 than their 0157: H7 strains. The high prevalent rate of $E$. coli isolated from nono could be an indication of the poor quality of water used or an indication of the unsanitary condition under which the products are produced. Obi and Ikenebomeh, (2007) reported the presence of pathogenic organisms in nono which included $E$. coli and other enteric bacteria after production. They suggested that nono be pasteurized after its fermentation before being sold to consumers so as to make it safe for consumption.

The major virulent factor and a defining characteristic of Enterohemorrhagic $E$ coli (EHEC) is shiga toxin (stx). Nataro and Kaper (1998) reported that this potent toxin is the major factor that leads to death and many other symptoms in patients infected with EHEC. O'Brien et al., (1992) reported that the stx family contain two major immunological noncross reactive groups called stx 1 and stx 2, with a single EHEC strain possibly expressing stx 1 only, stx 2 only or both toxins. They posited that some EHEC strains even express multiple forms of stx1 genes. Jackson et al. (1987) reported that the prototypical stx 1 and stx2 toxins are known to have about 55 and 57 $\%$ sequence identity in the $A$ and $B$ subunits, respectively, and that while stx 1 is highly conserved, sequence variation exists within stx 2. Shiga toxin gene detection of non- $0157 E$. coli from Nono sold in Nigeria showed that $40 \%$ of the isolates carry the stx 1 gene alone while $38 \%$ harbour the stx2 gene alone, only $4 \%$ harbour both stx 1 and stx 2. Mathusa et al. (2011) reported that illnesses linked to STEC serotypes other than $0157: \mathrm{H} 7$ appear to be on the rise in the United States and worldwide, indicating that some of these organisms may be emerging pathogens. They noted that various virulence factors are involved in non0157 STEC pathogenicity with the combined presence of both eae and stx genes associated with enhanced virulence. They also noted that although substantial progress has been made, a practical method of STEC detection has yet to be validated making the rapid detection of the organism difficult.

The use of vero cells to confirm verotoxin or shiga toxin production in microorganisms have been indicated by various authors (Konowalchuck et al., 1977; Karmali et al., 1983; O'Brien et. al., 1983; Riley et.al., 1983; Johnson et. al., 1983). Since it was first observed by Konowalchuck et al. (1977), cytotoxicity to vero cell line has remained a "gold standard" for confirming putative shiga toxin producing isolates, especially as it has been proven that vero cells have a high concentration of globotriaosylceramide (Gb3) and globotetraosylceramide (Gb4) toxin-binding 
receptors in their plasma membranes and will detect all variants of verotoxins (Mora et al., 2004). Tissue culture assay to determine their pathogenic potential on vero cells showed that $74 \%$ of the isolates harbouring only stx 1 elicited strong cytotoxic effect on vero cells and $80 \%$ of isolates harbouring only stx 2 having between strong and very strong cytotoxic effect on vero cells. Few of the isolates harbouring stx 1 and stx 2 alone also showed excellent cytotoxic effect on vero cells. Those isolates with st $x 1$ and st $x 2$ though very few, elicited very very strong cytotoxic effect on vero cells. Majority of the isolates without stx elicited weak cytotoxic effect on vero cells. These results indicate a strong relationship between the presence of stx and the degree of cytotoxic effect on vero cells, supporting the view of Gyles (2007) that shiga toxin is the critical factor in STEC diseases. The fact that some isolates not harbouring the stx gene showed some level of cytotoxic effect indicates that

\section{REFERENCES}

Abdalla W.M. and El-Zubeir, I.E.M. (2006). Microbial hazards associated with fermented milk (Roub and Mish) processing in Sudan. Int. J. Dairy Sci., 1: $21-26$

Adesiyun A.A., Webb L. and Rahaman, S. (1995). Microbiological quality of raw cow's milk at collection centers in Trinidad. J. Food Prot., 58: 139-146.

Blackburn C. W. and McCarthy J. O. (2000). Modifications to method for the enumeration and detection of injured $\mathrm{E}$. coli 0157:H7 in foods. Int J. of Food Microbiol. 55: 285 - 290.

Blanco M., Blanco J.E., Mora A., Ray J., Alonso J. M., Hermoso M., Hermoso J., Alonso M. P., Dhabi G., Gonzalez E. A., Bernardez E. I. and Blanco J. (2003). Serotypes, virulence genes and intimin types of Shiga toxin (verotoxin) producing Escherichia coli isolates from healthy sheep in Spain. J. Clin. Microbiol. 42: 645 - 651.

Bosilevac J. M. and Koohmaraie M. (2011). Prevalence and Characterisation of non-0157 shiga-toxin producing other virulence factors could be present in the E coli. Nataro and Kaper (1998) gave a detailed review of these virulence factors which include the presence of intestinal adherence factors and haemolysin encoding genes.

Conclusively, this study not only established the presence of non 0157:H7 E. coli in Nono sold in Nigeria, but it also showed that Nono could be a potential public health hazard. This study also provides a baseline data on non 0157 STEC infection in Nigeria. Effort should therefore be made by local and National health authorities to properly monitor the way Nono and other related food products are processed and sold. It is recommended that proper surveillance strategies should also be put in place aimed at identifying actual causative agents of food borne infections reported in the hospitals, especially those reported from the rural areas where these food products are mostly consumed.

Escherichia coli isolates from commercial ground beef in the United States. Appl. Environ. Microbiol. 77(6): 2103-2112

CDC (Centres for Disease Control and Prevention). (2009). Recommendations for diagnosis of Shiga toxin-producing Escherichia coli infections by clinical laboratories. Morb. Mort. Wkly. Rep. 58(RR-12):1-14.

Ekici K., Bozkurt $H$. and Isleyici, $O$. (2004). Isolation of some pathogens from raw milk of different milch animals. Pak. J. Nutr., 3: 161-162.

Fey P. D. Wickert, R. S. Rupp, M. E. Safranek, T. J. and Hinrichs S. H. (2000). Prevalence of Non-0157:H7 Shiga Toxin-Producing Escherichia coli in Diarrheal Stool Samples from Nebraska. Emerging Infectious Diseases 6(5), 530 - 533

Franzolin M. R., Keller R., Gomes T. A., Beutin L., Barreto M. L., Milray C., Straina A., Ribeiro H. And Trabulsi I. R. (2005). Prevalence of diarrheagenic $E$. coli in children with diarrhea in 
Salvador, Bahia, Brazil. Mem. Inst.Oswaldo Cruz. 100 (4): 359 - 363.

Gyles C. L. (2007). Shiga toxin- producing Escherichia coli: An overview. J. Anim. Sci. 85: E45-E62

Holt J. G, Krevy H.S, Sneathe R.H.A, Williams S.T. (1994). Bergey's Manual of Determinative Bacteriology 9th Edition. Williams and Wilkens Company, Baltimore, USA.

Hussein H. S. (2007). Prevalence and Pathogenicity of Shiga- toxin producing Escherichia coli in beef cattle and their products. J. Anim. Sci. 85(E.Suppl): E63-E72.

Jackson M. P., Neill R. J., O'Brien A. D., Holmes R. K. and Newland J. W. (1987). Nucleotide sequence analysis and comparison of the structural genes for Shiga-like toxin I and Shiga-like toxin II encoded by bacteriophages from Escherichia coli 933. FEMS Microbiol. Lett. 44:109-114.

Johnson W. M., Lior H., and Bezanson G. S. (1983). Cytotoxic Escherichia coli 0157:H7 associated with haemorrhagic colitis in Canada. Lancet i:76. (Letter.)

Johnson R. P, Clarke R.C., Wilson J.B., Read S.C., Rahn K., Renwick S.A., Sandhu K.S., Alves D., Karmali M.A., Lior H., McEwen S.A., Spika J.S., and Gyles C.L. (1996). Growing concerns and recent outbreaks involving non0157:H7 verotoxigenic Escherichia coli. Food Prot. 59:1112-1122.

Johnson K. E, Thorpe C. M, Sears C. L. (2006). The emerging clinical importance of non- 0157 Shiga toxin-producing Escherichia coli. Clin Infect Dis, 43:1587-95.

Karmali M. A., Steele, B. T. Petric, M. and Lim. C. (1983). Sporadic cases of haemolytic uraemic syndrome associated with faecal cytotoxin and cytotoxin-producing Escherichia coli in stools. Lancet 1:619-620.

Kaper J. B., Nataro J. P. and Mobley H. L. (2004). Pathogenic Escherichia coli. Nat. Rev. Microbiol. 2:123-140.
Konowalchuk J., Speirs J. I., and Stavric S. (1977). Vero response to a cytotoxin of Escherichia coli. Infect. Immun. 18:775-779.

Mathusa E. C., Chen Y., Enache E. Hontz L. (2010). Non-0157 Shiga toxinproducing Escherichia coli in foods. J. Food Prot. 73(9):1721-36.

Mora A., Blanco M., Blanco J.E., Alonso M.P., Dhabi G., Thompson-Carter F., Usera M.A. and Bartolome R. (2004). Phage types and genotypes of human and animal Shiga toxin-producing Escherichia coli 0157:H7 in Spain. Identification of two predominating phage types (PT2 and PT8). J Clin Microbiol 42: 4007-4015

Nataro J. P. and Kaper J. B. (1998). Diarrheagenic Escherichia coli. Clin. Microbiol. Rev. 11: 142 - 201

Nebedum J.O. and Obiakor T. (2007). The effects of different preservation methods on the quality of nono: A locally fermented Nigerian Dairy Product. Afr. J. Biotechnol., 6: 454-458.

Obi C.N. and Ikenebomeh, M..J. (2007). Studies on the microbiology and nutritional qualities of a Nigerian fermented milk product (Nono). Int. J. Dairy Sci., 2: 95-99.

O'Brien A. D., Lively T. A., Chen M. E., Rothman S. W., and Formal S. B. (1983). Escherichia coli 0157:H7 strains associated with haemorrhagic colitis in the United States produce a Shigella dysenteriae 1 (Shiga) like cytotoxin. Lancet i:702

O'Brien A. D., Tesh V. L., Donohue-Rolfe A., Jackson M. P., Olsnes S., Sandvig K., Lindberg A. A. and Keusch G. T. (1992). Shiga toxin: biochemistry, genetics, mode of action, and role in pathogenesis. Curr. Top. Microbiol. Immunol. 180:65-94.

Ogbonna I. O. (2011). Microbiological analyses and safety evaluation of Nono: a fermented milk product consumed in most parts of Northern Nigeria. Inter. J. Dairy Sci. 6: 181-189. 
Pradel N., Livrelli V., De Champs C., Palcoux J. B. Raynaud A. Sheutz F., Sirot J. and Forestier C. (2001). Prevalence and characterisation of shiga toxin producing E.coli isolated from cattle, food and children during one year prospective study in France. J. Clin. Microbiol. 38:1023-1031

Rahn K., Wilson J. B. Mcfadden K. A. Read S. C. Ellis A. G. Renwick S. A., Clarke R. C., and Johnson R. P. (1996). Comparison of Vero cell assay and PCR as indicators of the presence of verocytotoxigenic Escherichia coli in bovine and human fecal samples. Appl. Environ. Microbiol. 62(12): 4314 4317.

Riley L. W., R. S. Remis, S. D. Helgerson, H. B. McGee, J. G. Wells, B. R. Davis, R. J. Hebert, E. S. Olcott, L. M. Johnson, N. T. Hargrett, P. A. Blake, and M. L. Cohen. (1983). Hemorrhagic colitis associated with a rare Escherichia coli serotype. N. Engl. J. Med. 308:681685.

Sambrook J. and Russell, D. W. (2001). Molecular cloning: A Labooratory Manual vol 2. Cold Spring Habour Lab. Press New York. p126

Scallan E.1, Hoekstra R.M, Angulo F.J, Tauxe R.V, Widdowson M.A, Roy S.L, Jones J.L, Griffin P.M.. (2011). Foodborne illness acquired in the United States major pathogens. Emerg Infect Dis, 17: 7-15

Solomon E. B., Yaron S. and Mathews K. R. (2002). Transmission of Escherichia coli 0157:H7 from contaminated manure and irrigation water to lettuce plant tissue and its subsequent internalization. Appl. Environ. Microbiol. 68: 397-400.

Vernozy-Rozand C. (1997). Detection of Escherichia coli 0157:H7 and other verocytotoxin - producing $E$. coli (VTEC) in food. J. of Appl. Microbiol. 82: $537-551$. 